\title{
X-Ray Crystal Structure and Cation Binding Properties of a New Phthalide-fused Indoline Derivative
}

(Struktur Hablur Sinar-X dan Sifat Pengikat Kation bagi Terbitan Ftalida-Indolin)

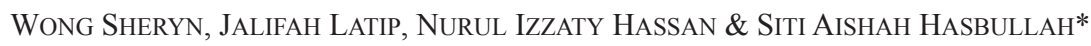

\begin{abstract}
An efficient and a green route to synthesize phthalide-fused indoline, 3-[(5-chloro-1,3,3-trimethylindolin-2-ylidene)methyl] isobenzofuran-1(3H)-one (3) has been developed by the coupling reaction of 5-chloro-2-methylene-1,3,3-trimethylindoline, 1 and 2-formylbenzoic acid, 2 under solvent-free domestic microwave irradiation. The compound was produced in 85\% yield. Compound 3 was characterized by analytical and spectral methods and its structure was confirmed by chemical crystallography. Compound 3 was successfully crystallized in triclinic system with space group P $\bar{\imath}$. The molecular structure consists of fused 1 and $\mathbf{2}$ groups connected by the enamine carbon. Binding study of 3 towards different types of metal cations was done by colorimetric detection and UV-vis titrations. Compound 3 exhibited good selectivity and sensitivity for $\mathrm{Sn}^{2+}$ compared to other metal cations tested. The stoichiometric binding ratio of 3 toward $\mathrm{Sn}^{2+}$ is found to be $1: 1$ and the binding constant $\left(K_{a}\right)$ is $1.07 \times 10^{4} M^{-1}$ on the basis of Job's plot and Benesi-Hildebrand analysis.
\end{abstract}

Keywords: Binding study; chemical sensor; green synthesis; Phthalide-indoline; Sn(II) ion

ABSTRAK

Satu kaedah sintesis hijau dan cekap bagi sintesis ftalida-indolin, 3-[(5-kloro-1,3,3-trimetilindolin-2-ylidin)metil] isobenzofuran-1(3H)-on (3), telah dibangunkan melalui tindak balas pengkupelan antara 5-kloro-2-metilin-1,3,3trimetilindolin, 1 dan asid 2-formilbenzoik, 2 menggunakan iradiasi gelombang mikro tanpa pelarut dengan peratusan 85\%. Sebatian 3 telah dicirikan melalui kaedah analisis dan spektrum, serta strukturnya disahkan melalui kristalografi kimia. Hablur tunggal sebatian 3 telah berjaya dihasilkan dan mempunyai sistem hablur triklinik dengan kumpulan ruang Pì. Struktur molekul 3 adalah merupakan gabungan kumpulan 1 dan 2 yang berikat pada karbon enamin. Kajian pengikatan antara sebatian 3 dengan pelbagai kation logam telah dijalankan menggunakan kaedah kolorimetri dan kaedah pentitratan ultralembayung boleh nampak (UV-vis). Sebatian 3 menunjukkan kepilihan dan kepekaan yang baik terhadap ion $\mathrm{Sn}^{2+}$ berbanding dengan kation logam lain yang diuji. Nisbah stoikiometri pengikatan antara 3 dengan $\mathrm{Sn}^{2+}$ dan pemalar pengikatan $\left(K_{a}\right)$ masing-masing adalah $1: 1$ dan $1.07 \times 10^{4} \mathrm{M}^{-1}$ berdasarkan plot Job dan analisis Benesi-Hildebrand.

Kata kunci: Ftalida-indolin; ion Sn(II); kajian pengikatan; penderia kimia; sintesis hijau

\section{INTRODUCTION}

Study on selective and sensitive chemosensors are widely attractive because of their instantaneous response toward a certain analyte, high sensitivity with low limit of detection, accuracy and uncomplicated design as compared to the costly conventional method of detecting metal ions (Li \& Xiao 2016; Qu et al. 2017). Heterocyclic molecule with ring opening ability is one of the important aspects in designing a highly selective and sensitive chemosensor (Chatterjee et al. 2016). Colorimetric chemosensor has also attracted much attention whereby a target analyte can be identified by 'naked eye' (Zhu et al. 2015). In a recent study on tin compounds in landfill leachates, $\mathrm{Sn}^{2+}$ ionic species exhibited bacterial methylation forming toxic methyltin which may be released into the environment (Peeters et al. 2014). $\mathrm{Sn}^{2+}$ and inorganic tin compounds have several unfavourable biological effects on human and moderate toxicity to aquatic organisms and the environment (Howe $\&$ Watts 2005). Meanwhile in another study by Mathews et al. (2015), $\mathrm{Sn}$ (II) chloride was successfully used as a treatment system to remove mercury from wastewater, however, possible impacts of tin bioaccumulation toward human or ecological risk may be of concern. Thus, an in situ method of detecting and quantifying tin metal ions is essential in monitoring the environmental and biological systems.

Phthalides, also known as isobenzofuranones, are classified under lactones with its five-membered O-heterocyclic ring and is fused with benzene. 3-substituted phthalides are usually found in natural products and are well known for their wide range of biological application (Beck \& Chou 2007; Karmakar et al. 2014). It is also one of the main classes in the production of commercial dyes (Bamfield 2010). Indoline, an aromatic N-heterocycle, 
possess biological activities like antibacterial (Michael Barbour et al. 2014) and cytotoxicity against cancer cells (Azizian et al. 2012). Besides, it is also a building block of highly conjugated cyanine with good optical properties, great biocompatibility and low toxicity toward biosamples (Sun et al. 2016). These are the desirable properties of a chemosensor.

Much effort is being expended in synthesizing natural products containing the phthalide and N-heterocyclic moiety. Green route of synthesizing 3-substituted phthalides using the microwave irradiation was reported with better yield and efficiency (Landge et al. 2008; Srivastava et al. 2013). The use of microwave irradiation in reaction provides many advantages which include performing solventless reactions, reduction of time taken for a reaction, instantaneous and efficient heating and less waste production (Gangrade et al. 2015). This work will follow the green route of synthesis whereby reaction will be done in a solventless medium using the microwave irradiation method.

\section{MATERIALS AND METHODS}

Reaction was performed under microwave irradiation method using a domestic microwave oven (Electrolux, model EMM2017X, PCR). Chemicals and solvents were purchased from Sigma Aldrich and Systerm and used directly without further purification. All UV-vis spectra were recorded on Shimadzu UV-1800 spectrophotometer using a quartz cell with a path length of $1 \mathrm{~cm}$ in $95 \% \mathrm{ETOH}$; FTIR spectrum was recorded on Perkin-Elmer Spectrum GX spectrophotometer in the range $400-4000 \mathrm{~cm}-1$ using $\mathrm{KBr}$ pellet method; $1 \mathrm{H}$ and $13 \mathrm{C} \mathrm{NMR} \mathrm{(in} \mathrm{CDCl} 3$ ) spectra recorded on a Bruker Avance $400 \mathrm{MHz}$ spectrometer at 400.2 MHz and at 100.6 MHz, respectively using TMS as internal standard; mass spectrum recorded on a Bruker micrOTOF-Q spectrometer by ESI-MS in the positive ion mode. Single crystal X-ray experiments were performed on Bruker D8 QUEST diffractometer with MoK $\alpha$ radiation.

\section{MICROWAVE IRRADIATION METHOD}

A mixture of 5-chloro-2-methylene-1,3,3-trimethylindoline, 1 (1 mmol) and 2-formylbenzoic acid, 2 (1 mmol) was added into a dry reaction vial. The mixture was then irradiated using a domestic microwave at $100 \mathrm{~W}$ for $1 \mathrm{~min}$. The reaction was monitored by TLC (petroleum ether/ethyl acetate, 2:1). After reaction was completed, cold ethanol $(2 \mathrm{~mL})$ was added into the reaction mixture. Precipitate was formed upon sonication for $10 \mathrm{~s}$. The reaction mixture was then evaporated to approximately half its original volume and the precipitate was filtered off. The crude product was crystallized by slow evaporation from acetone to obtain pure crystal plates.

3-[(5-Chloro-1,3,3-trimethylindolin-2-ylidene)methyl]isobenzofuran$1(3 H)$-one $(3)$

The compound was obtained as greenish-yellow crystals in $85 \%$ yield $(0.29 \mathrm{~g})$. UV (EtOH): $1_{\max }=226,290 \mathrm{~nm}$. IR vmax $(\mathrm{KBr}) / \mathrm{cm}^{-1}: 3053\left(\mathrm{C}-\mathrm{H} \mathrm{sp}{ }^{2}\right), 2928,2960\left(\mathrm{C}-\mathrm{H} \mathrm{sp}{ }^{3}\right)$, $1750(\mathrm{C}=\mathrm{O}), 1649(\mathrm{C}=\mathrm{C}), 1466,1493,1602$ (aromatic $\mathrm{C}=\mathrm{C}), 1139,1287(\mathrm{C}-\mathrm{O}), 1062,1094,1265(\mathrm{C}-\mathrm{N}), 900 .{ }^{1} \mathrm{H}$ NMR $\left(400 \mathrm{MHz} ; \mathrm{CDCl}_{3}\right) \mathrm{dH} 1.70\left(6 \mathrm{H}, \mathrm{s}, \mathrm{CH}_{3}\right), 3.00(3 \mathrm{H}, \mathrm{s}$, $\left.\mathrm{N}-\mathrm{CH}_{3}\right), 4.21(1 \mathrm{H}, \mathrm{d}, J=10.8 \mathrm{~Hz}, \mathrm{CH}-\mathrm{O}), 6.51(1 \mathrm{H}, \mathrm{d}, J=$ $\left.7.6 \mathrm{~Hz}, H_{\mathrm{Ar}}\right), 6.60(1 \mathrm{H}, \mathrm{d}, J=10.4 \mathrm{~Hz}, \mathrm{C}=\mathrm{CH}), 7.12(2 \mathrm{H}$, $\left.\mathrm{m}, J=8.0 \mathrm{~Hz}, H_{\mathrm{Ar}}\right), 7.45\left(1 \mathrm{H}, \mathrm{d}, J=6.8 \mathrm{~Hz}, H_{\mathrm{Ar}}\right), 7.56$ $\left(1 \mathrm{H}, \mathrm{t}, J=6.8 \mathrm{~Hz}, 7.2 \mathrm{~Hz}, H_{\mathrm{Ar}}\right), 7.70(1 \mathrm{H}, \mathrm{t}, J=6.4 \mathrm{~Hz}$, $\left.7.2 \mathrm{~Hz}, H_{\mathrm{Ar}}\right), 7.91\left(1 \mathrm{H}, \mathrm{d}, J=7.2 \mathrm{~Hz}, H_{\mathrm{Ar}}\right) .{ }^{13} \mathrm{C}$ NMR $(100$ $\left.\mathrm{MHz}, \mathrm{CDCl}_{3}\right) 29.2,29.9\left(\mathrm{CH}_{3}-\mathrm{C}-\mathrm{CH}_{3}\right), 45.2\left(\mathrm{~N}-\mathrm{CH}_{3}\right), 79.1$ $(\mathrm{C}=\mathrm{CH}), 88.7(\mathrm{CH}-\mathrm{O}), 106.4\left(\mathrm{CH}_{\mathrm{Ar}}\right), 122.1\left(\mathrm{CH}_{\mathrm{Ar}}\right), 122.7$ $\left(C \mathrm{H}_{\mathrm{Ar}}\right), 124.3\left(C_{\mathrm{Ar}}-\mathrm{Cl}\right), 125.4\left(C_{\mathrm{Ar}}\right), 126.4\left(C_{\mathrm{Ar}}\right), 127.7$ $\left(C \mathrm{H}_{\mathrm{Ar}}\right), 129.1\left(\mathrm{CH}_{\mathrm{Ar}}\right), 134.1\left(\mathrm{CH}_{\mathrm{Ar}}\right), 139.7\left(C_{\mathrm{Ar}}\right), 143.8$ $\left(C_{\mathrm{Ar}}\right), 150.9\left(C_{\mathrm{Ar}}\right), 160.9(\mathrm{~N}-C=\mathrm{CH}), 170.7(C=\mathrm{O})$. ESIMS m/z calcd for $\mathrm{C}_{20} \mathrm{H}_{18} \mathrm{ClNO}_{2} \mathrm{Na}\left[\mathrm{M}+\mathrm{Na}^{+}: 362.0924\right.$. Found: 362.0921 .

\section{SAMPLE PREPARATION FOR BINDING STUDY WITH METAL CATIONS}

For colorimetric detection of metal ions, stock solutions $\left(1 \times 10^{-3} \mathrm{M}\right)$ of $\mathbf{3}$ and metal ions $\left(\mathrm{Ag}^{+}, \mathrm{Co}^{2+}, \mathrm{Cu}^{2+}, \mathrm{Fe}^{2+}\right.$, $\mathrm{Hg}^{2+}, \mathrm{Ni}^{2+}, \mathrm{Sn}^{2+}$ and $\mathrm{Zn}^{2+}$ ) were prepared in $95 \% \mathrm{EtOH}$, respectively. The color change of $1 \mathrm{~mL}$ of $3\left(5 \times 10^{-4} \mathrm{M}\right)$ was observed immediately after mixing with $1 \mathrm{~mL}$ of stock solution of respective metal ions. Metal ion screening was further analyzed by UV-vis absorption by diluting 50 $\mathrm{mL}$ of stock solution of $\mathbf{3}$ and $100 \mathrm{~mL}$ of stock solution of respective metal ions in a $5 \mathrm{~mL}$ volumetric flask with $\mathrm{EtOH}$. The final concentrations of $\mathbf{3}$ and metal ions were $1 \times 10^{-5} \mathrm{M}$ and $2 \times 10^{-5} \mathrm{M}$, respectively.

For UV-vis titration, stock solutions of $\mathbf{3}\left(1 \times 10^{-5} \mathrm{M}\right)$ and $\mathrm{SnCl}_{2}\left(1 \times 10^{-3} \mathrm{M}\right)$ were prepared. $3 \mathrm{~mL}$ of $\mathbf{3}$ was taken directly into a quartz cuvette. The spectral measurements were recorded after each aliquot addition $(10 \mathrm{~mL})$ of the metal cation solution using a micropipette. All titration experiments were recorded at room temperature.

The stoichiometric ratio between 3 and $\mathrm{Sn}^{2+}$ ions was studied using Job's plot. Equimolar $\left(1 \times 10^{-3} \mathrm{M}\right)$ stock solutions of 3 and $\mathrm{Sn}^{2+}$ ions were prepared in $95 \% \mathrm{EtOH}$. Both the compound $\mathbf{3}$ and $\mathrm{Sn}^{2+}$ ions were mixed at different volumes (from 0 to $200 \mathrm{~mL}$ ) in $10 \mathrm{~mL}$ volumetric flasks and was diluted with EtOH to make a total volume of 10 $\mathrm{mL}$. Each volumetric flask had a total concentration of $\mathbf{3}$ and $\mathrm{Sn}^{2+}$ of $2 \times 10^{-5} \mathrm{M}$. The UV-vis spectra were taken at room temperature.

\section{RESULTS AND DISCUSSION}

\section{SYNTHESIS AND CHARACTERIZATION}

Compound $\mathbf{3}$ was synthesized from the reaction of a Fischer base and phthalaldehydic acid. The reaction scheme is shown in Scheme 1. Compound 3 was synthesized in a quantitative yield of $85 \%$ by microwave irradiation.

The UV spectrum of $\mathbf{3}$ in ethanol displayed absorption maximum at around $226 \mathrm{~nm}$ and $290 \mathrm{~nm}$ indicative of aromatic ring compounds due to $\pi \rightarrow \pi^{*}$ of benzene chromophores and $\mathrm{n} \rightarrow \pi^{*}$ transition of carbonyl groups. 


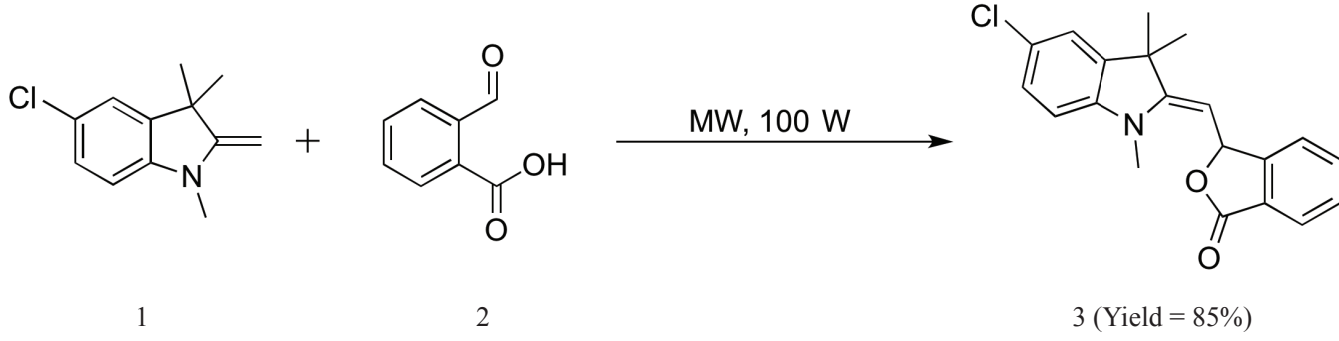

SCHEME 1. Preparation of a phthalide-fused indoline derivative under microwave irradiation

The FTIR spectrum showed characteristic $\mathrm{C}=\mathrm{O}$ stretch of lactone ring at $1750 \mathrm{~cm}^{-1}$ (Figure 1). Bands between 1062 and $1287 \mathrm{~cm}^{-1}$ were assigned as $\mathrm{C}-\mathrm{O}$ and $\mathrm{C}-\mathrm{N}$ stretching.
${ }^{1} \mathrm{H}$ NMR spectrum (Figure 2) of compound $\mathbf{3}$ displayed 18 hydrogen integrals. According to report by Keum et al. (2011), the indoline group showed regular ${ }^{1} \mathrm{H}$ NMR resonance pattern for the protons on adjacent methyl

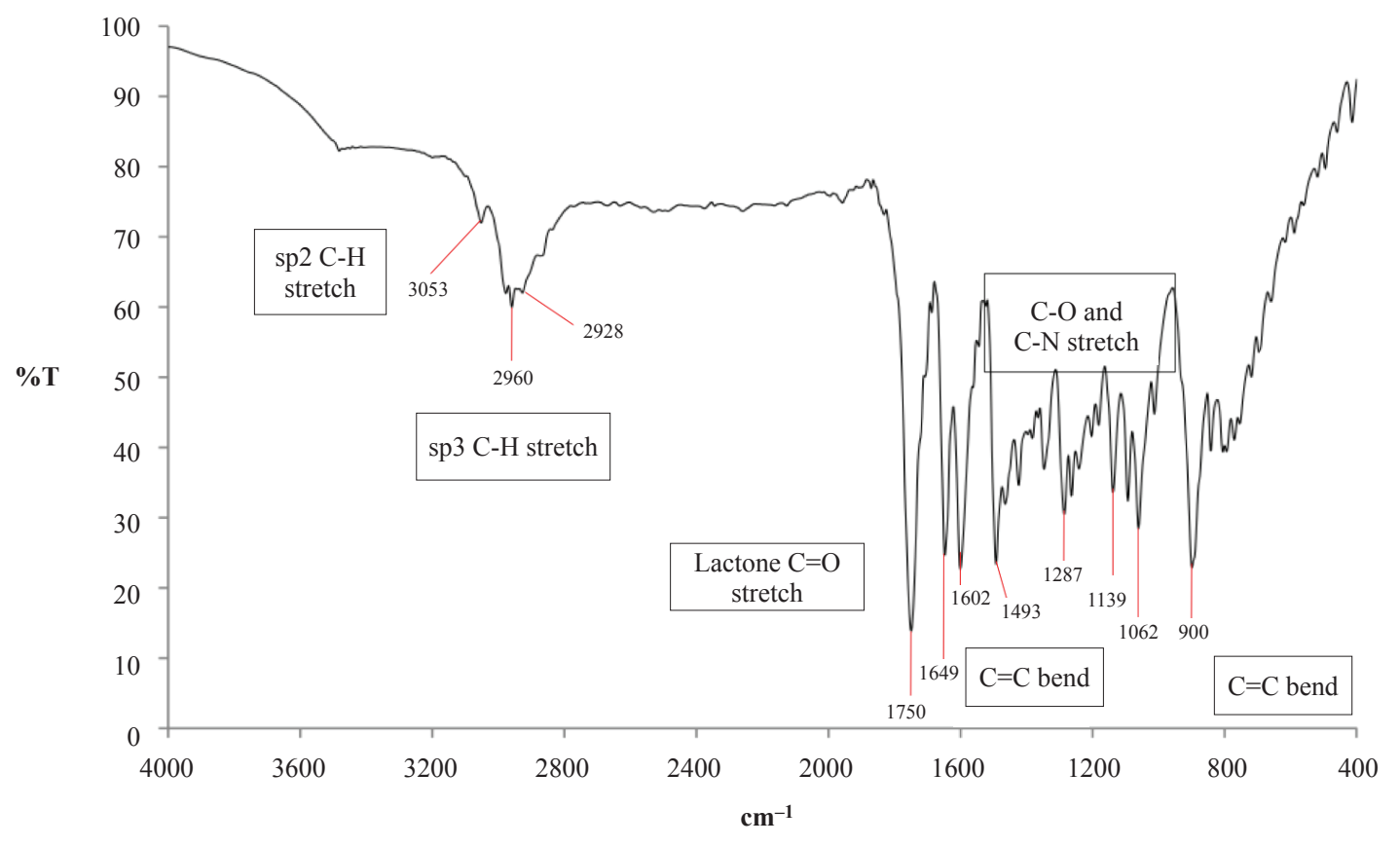

FIGURE 1. FTIR spectrum of $\mathbf{3}$

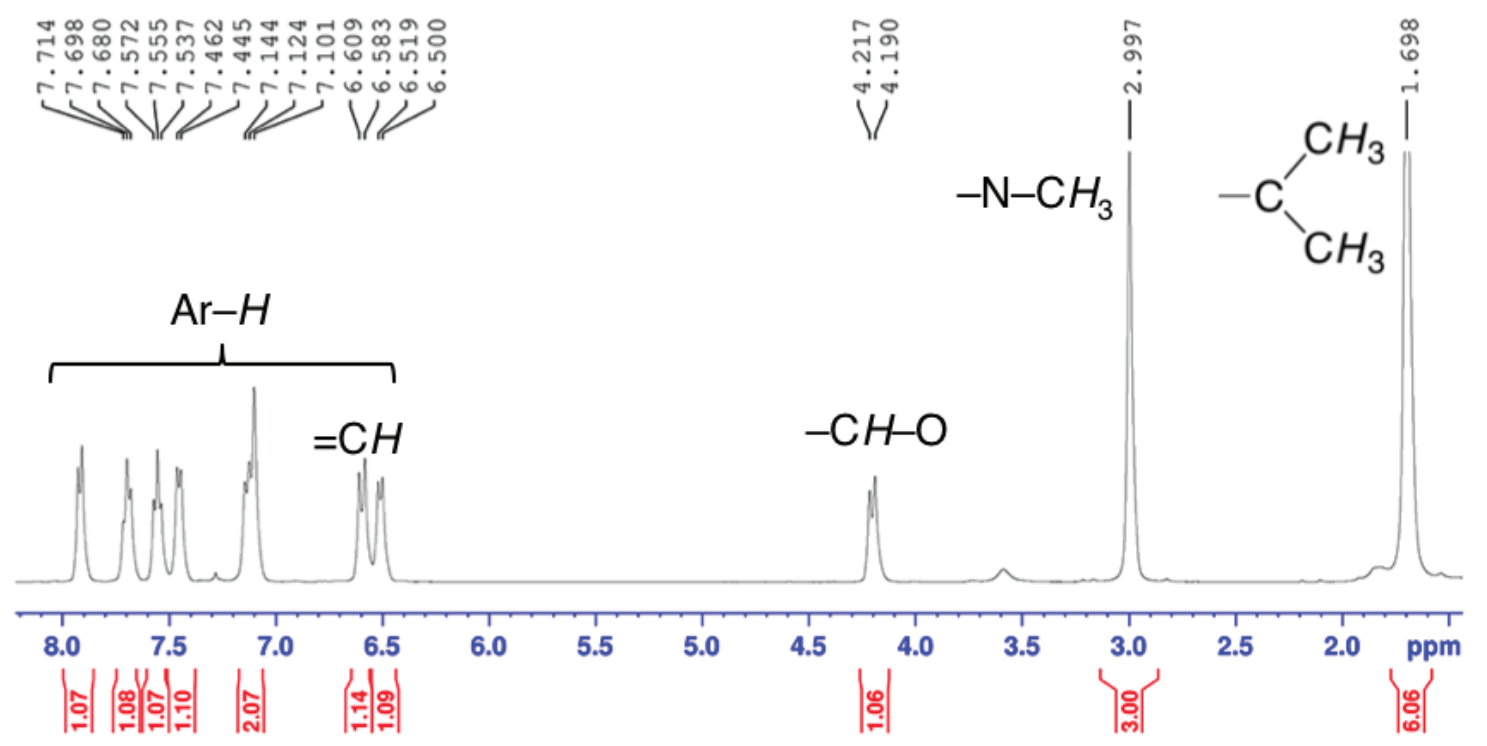

FIGURE 2. ${ }^{1} \mathrm{H}$ NMR of $\mathbf{3}$ 
groups. The gem-dimethyl protons appeared as a singlet at $1.70 \mathrm{ppm}$, while $\mathrm{N}$-methyl protons resonated at 3.00 $\mathrm{ppm}$. A doublet at $4.20 \mathrm{ppm}$ belongs to the chiral $\mathrm{CH}-\mathrm{O}$ proton. The olefinic proton was detected as a multiplet at $6.60 \mathrm{ppm}$, with a $J$ value of $10.4 \mathrm{~Hz}$. Peaks between 6.5 and $8.0 \mathrm{ppm}$ were resonated by aromatic protons. The ${ }^{13} \mathrm{C}$ NMR spectrum had 19 discrete carbon resonance signals and each peak was assigned by comparing to the spectrum of a phthalide-fused indoline derivative reported by Chunaev et al. (1982).

The molecular weight of $\mathrm{C}_{20} \mathrm{H}_{20} \mathrm{NO}_{2}$ is $339.8190 \mathrm{~g} / \mathrm{mol}$. The ESI-MS spectrum showed an intense pseudomolecular ion peak at $\mathrm{m} / \mathrm{z} 362.0921,[\mathrm{M}+\mathrm{Na}]^{+}$.

\section{X-RAY CRYSTALLOGRAPHY}

Single crystal of $\mathbf{3}$ was subjected to X-ray crystallographic analyses to further confirm its chemical structure. The crystal was grown by slow evaporation of acetone solution at room temperature. Compound $\mathbf{3}$ crystallized in monoclinic system with space group $\mathrm{P} \overline{1}$. The crystal system and refinement parameters are shown in Table 1.

The molecule 3 consists of two fused 5-chloro-2methylene-1,3,3-trimethylindoline and isobenzofuran$1(3 H)$-one groups connected by the enamine carbon $\mathrm{C} 9$ (Figure 3) with C8-C9 and C9-C10 of bond lengths 1.475 (3) and 1.335 (3) $\AA$, respectively.

\section{BINDING STUDY WITH METAL IONS}

The colorimetric detection of mixture of compound $\mathbf{3}$ and metal salts were done qualitatively and observed by naked eyes. Color change was observed when colorless solution of compound $3\left(5 \times 10^{-4} \mathrm{M}\right)$ was mixed with 2 equivalent of $\mathrm{Fe}^{2+}$ and $\mathrm{Sn}^{2+}$, respectively (Figure 4). No color change was detected for all the other metal cations tested. The color of the mixture changed from colorless to greenish-yellow showed that compound $\mathbf{3}$ possessed ionochromic behavior with $\mathrm{Fe}^{2+}$ and $\mathrm{Sn}^{2+}$.

The interaction between compound $\mathbf{3}$ and various metal ions was studied by UV-vis spectroscopy in EtOH solution. Figure 5 shows the results of metal ion screening with $\mathbf{3}$. Solution of $\mathbf{3}$ was prepared at a concentration of $1 \times 10^{-5} \mathrm{M}$. No absorption band was found in the visible region from the absorption spectrum of $\mathrm{EtOH}$ solution of $\mathbf{3}$ and is, therefore, colorless. The UV-vis spectra of $\mathbf{3}$ $\left(1 \times 10^{-5} \mathrm{M}\right)$ was recorded upon addition of $\mathrm{Ag}(\mathrm{OAc})$, $\mathrm{CoCl}_{2}, \mathrm{Cu}(\mathrm{OAc})_{2}, \mathrm{FeSO}_{4}, \mathrm{HgI}_{2}, \mathrm{Ni}(\mathrm{OAc})_{2}, \mathrm{SnCl}_{2}$ and $\mathrm{Zn}(\mathrm{OAc})_{2}$ (2 equiv) in $95 \% \mathrm{EtOH}$ solution, respectively. New absorption band was seen with maximum absorbance at around $380 \mathrm{~nm}$ upon addition of $\mathrm{Sn}^{2+}$. The absorption spectrum of $\mathbf{3}$ upon addition of $\mathrm{Sn}^{2+}$ also showed a drop in the absorbance intensity at around $290 \mathrm{~nm}$, which may be an evidence of a host-guest complex interaction or binding. While upon the addition of other metal ions, no obvious change on the maximum absorbance or new band was detected. The absorbance intensity at $380 \mathrm{~nm}$ $\left(\mathrm{A}_{380 \mathrm{~nm}}\right)$ over the absorbance intensity of blank solution of 3 with various metal ions is represented in a chart
TABLE 1. Crystallographic data collection parameters for $\mathbf{3}$

\begin{tabular}{|c|c|}
\hline Compound & 3 \\
\hline Empirical formula & $\mathrm{C}_{20} \mathrm{H}_{18} \mathrm{Cl} \mathrm{N} \mathrm{O}$ \\
\hline Formula weight & 339.80 \\
\hline Temperature (K) & $304(2)$ \\
\hline Wavelength $(\AA)$ & 0.71073 \\
\hline Crystal system & Triclinic \\
\hline \multicolumn{2}{|l|}{ Space group } \\
\hline Unit cell dimensions $(\AA)$ & $\begin{array}{l}a=8.178(7) \\
b=10.163(8) \\
c=11.995(8)\end{array}$ \\
\hline$\alpha, \beta, \gamma\left(^{\circ}\right)$ & $\begin{array}{l}\alpha=83.46(4) \\
\beta=89.30(5) \\
\gamma=69.53(5)\end{array}$ \\
\hline Volume $\left(\AA^{3}\right)$ & $850.9(12)$ \\
\hline $\mathrm{Z}$ & 2 \\
\hline Density (calculated) $\left(\mathrm{Mg} / \mathrm{m}^{3}\right)$ & 1.326 \\
\hline Absorption coefficient $\left(\mathrm{mm}^{-1}\right)$ & 0.236 \\
\hline $\mathrm{F}(000)$ & 356 \\
\hline Crystal size (mm) & $0.60 \times 0.43 \times 0.25$ \\
\hline$\theta$ range $\left(^{\circ}\right)$ & $3.009-28.288$ \\
\hline Index ranges & $\begin{array}{l}-10 \leq \mathrm{h} \leq 10 \\
-13 \leq \mathrm{k} \leq 13 \\
-14 \leq 1 \leq 14\end{array}$ \\
\hline Reflections collected & 39140 \\
\hline Independent reflections & $4200[\mathrm{R}(\mathrm{int})=0.072]$ \\
\hline Completeness to theta & $99.3 \%$ \\
\hline Refinement method & $\begin{array}{l}\text { Full-matrix least-squares } \\
\text { on } \mathrm{F}^{2}\end{array}$ \\
\hline Data/restraints/parameters & $4200 / 0 / 221$ \\
\hline Goodness-of-fit on $\mathrm{F}^{2}$ & 1.046 \\
\hline Final $R$ indices $[\mathrm{I}>2 \operatorname{sigma}(\mathrm{I})]$ & $\begin{array}{l}\mathrm{R} 1=0.0559, \mathrm{wR} 2= \\
0.1320\end{array}$ \\
\hline $\mathrm{R}$ indices (all data) & $\begin{array}{l}\mathrm{R} 1=0.0925, \mathrm{wR} 2= \\
0.1577\end{array}$ \\
\hline Largest diff. peak and hole & 0.225 and -0.314 e. $\AA^{-3}$ \\
\hline CCDC No. & 1574258 \\
\hline
\end{tabular}

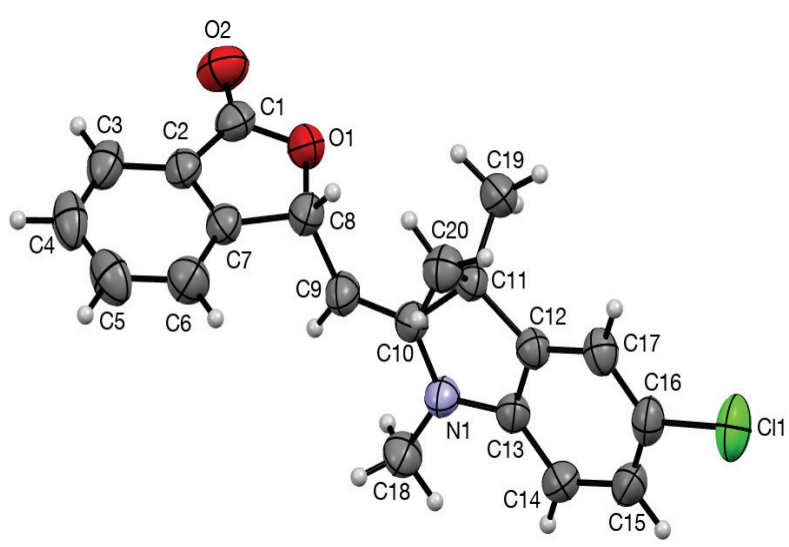

FIGURE 3. ORTEP diagram of $\mathbf{3}$ drawn at $50 \%$ probability ellipsoids 


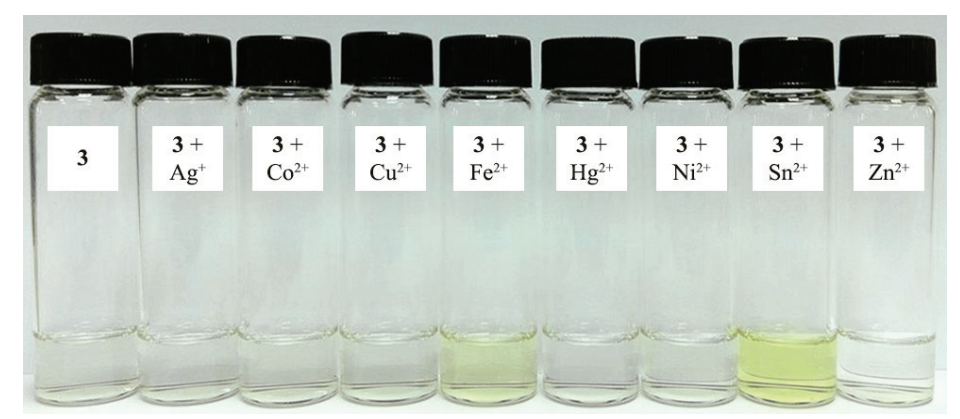

FIGURE 4. Colorimetric detection of 3 with metal salts of $\mathrm{Ag}(\mathrm{OAc}), \mathrm{CoCl}_{2}$, $\mathrm{Cu}(\mathrm{OAc})_{2}, \mathrm{FeSO}_{4}, \mathrm{HgI}_{2}, \mathrm{Ni}(\mathrm{OAc})_{2}, \mathrm{SnCl}_{2}$ and $\mathrm{Zn}(\mathrm{OAc})_{2}$

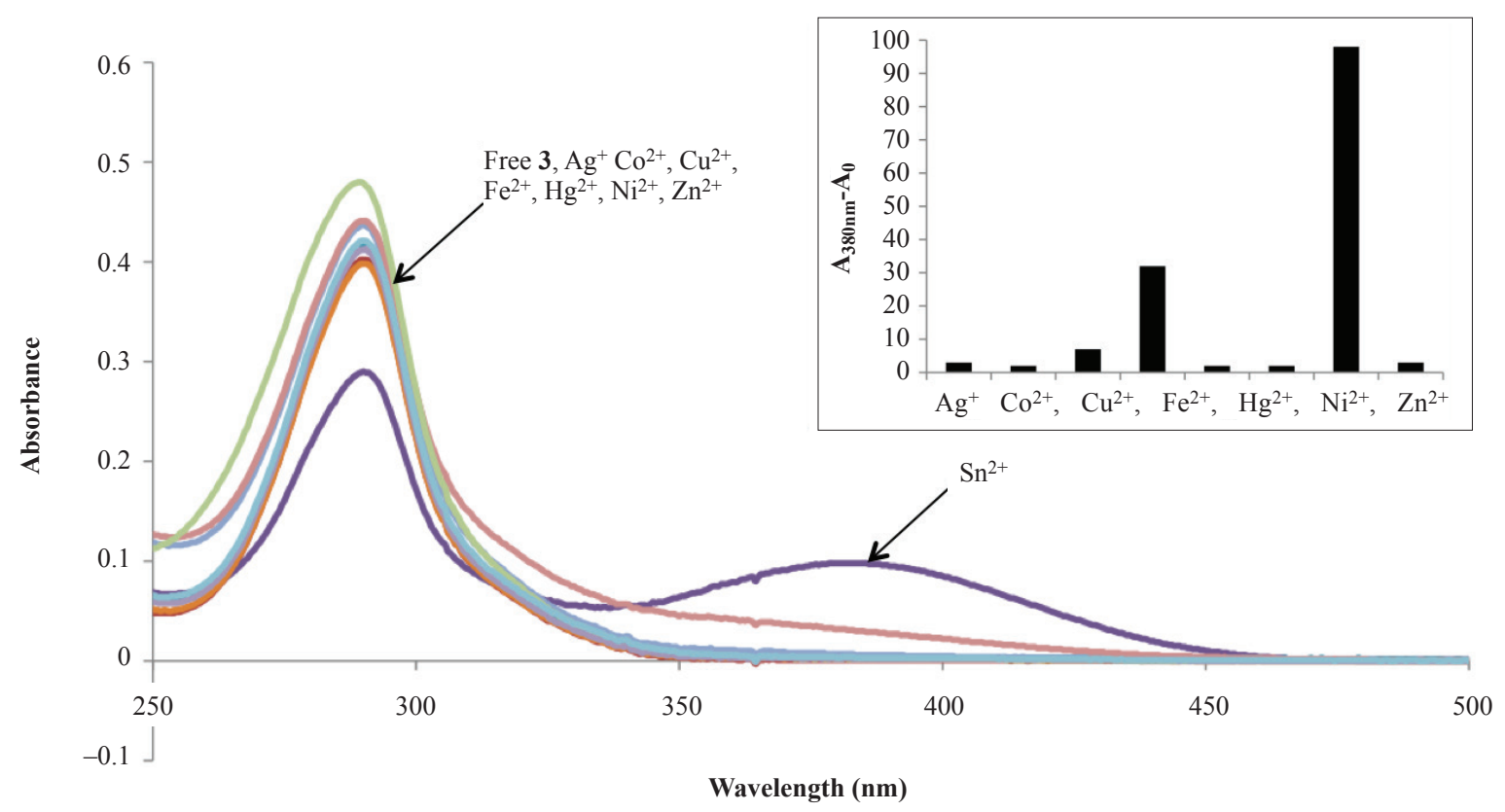

FIGURE 5. The absorption spectra of $\mathbf{3}$ upon addition of metal salts of $\mathrm{Ag}(\mathrm{OAc}), \mathrm{CoCl}_{2}, \mathrm{Cu}(\mathrm{OAc})_{2}, \mathrm{FeSO}_{4}, \mathrm{HgI}_{2}, \mathrm{Ni}(\mathrm{OAc})_{2}, \mathrm{SnCl}{ }_{2}$ and $\mathrm{Zn}(\mathrm{OAc})_{2}$ (2 equiv) in $95 \% \mathrm{EtOH}$ solution. Inset: Absorbance intensity at $380 \mathrm{~nm}, \mathrm{~A}_{380 \mathrm{~nm}}$ over that of blank solution of $\mathbf{3}, \mathrm{A}_{0}$

(Figure 5). With the addition of $\mathrm{Sn}^{2+}$ ions, the absorbance of 3 showed a remarkable increase in intensity as compared to the other metal ions.

The absorption spectra of $\mathbf{3}$ upon titration with $\mathrm{Sn}^{2+}$ in $95 \% \mathrm{EtOH}$ solution were recorded to further investigate the binding of $\mathbf{3}$ and $\mathrm{Sn}^{2+}$ ions. In the absence of $\mathrm{Sn}^{2+}$ ions, the free compound $\mathbf{3}$ remained colorless and did not exhibit any apparent absorption above $380 \mathrm{~nm}$. When the $\mathrm{Sn}^{2+}$ ion solution was added into the solution of $\mathbf{3}$, an increase in the absorption band at $380 \mathrm{~nm}$ was observed and the spectrum passed through two clear isobestic points at 261 and $315 \mathrm{~nm}$ (Figure 6). The increase in the absorbance and presence of the isobestic points are confirming the sensitivity of 3 towards $\mathrm{Sn}^{2+}$ ions in a solution and the formation of a new 3-Sn complex in equilibrium with the free compound 3 .

Next, a Job's plot was generated by the continuous variation method to determine the stoichiometric ratio between 3 and $\mathrm{Sn}^{2+}$ ions. In this method, each experiment was carried out with different concentrations of both 3 and $\mathrm{Sn}^{2+}$ ions while maintaining the total concentration at $20 \mathrm{mM}$. The plot was obtained by measuring the absorbance at $380 \mathrm{~nm}$ with mole fractions of $\mathrm{Sn}^{2+}$ from 0 to 1 . The Job's plot analysis showed a maximum at $\sim 0.5$ mole fraction of $\mathrm{Sn}^{2+}$, indicating that the $1: 1$ stoichiometry was the possible binding mode of $\mathbf{3}$ with $\mathrm{Sn}^{2+}$ (Figure 7).

The stoichiometric binding was again evaluated using the Benesi-Hildebrand method. The plot of 1/ $(D A)$ against $1 /\left[\mathrm{Sn}^{2+}\right]$ from the $\mathrm{UV}$-vis titration data showed a linear relationship implying that $\mathbf{3}$ associated with $\mathrm{Sn}^{2+}$ in a 1:1 stoichiometry (Figure 8 ). The value of association constant $\left(K_{a}\right)$ of $\mathbf{3}$ with $\mathrm{Sn}^{2+}$ was calculated from the value of intercept/slope to be $1.07 \times 10^{4} \mathrm{M}^{-1}$. This value is within the range $10^{3}-10^{5}$ of those reported for $\mathrm{Sn}^{2+}$-binding chemosensors (Adhikari et al. 2016; Bao et al. 2014; Jadhav et al. 2017; Qu et al. 2017; Wang et al. 2015). Hence, we propose the binding mode of 3 with $\mathrm{Sn}^{2+}$ via the formation of dianion through the ring opening of lactone according to Bamfield (2010) (Scheme 2). 


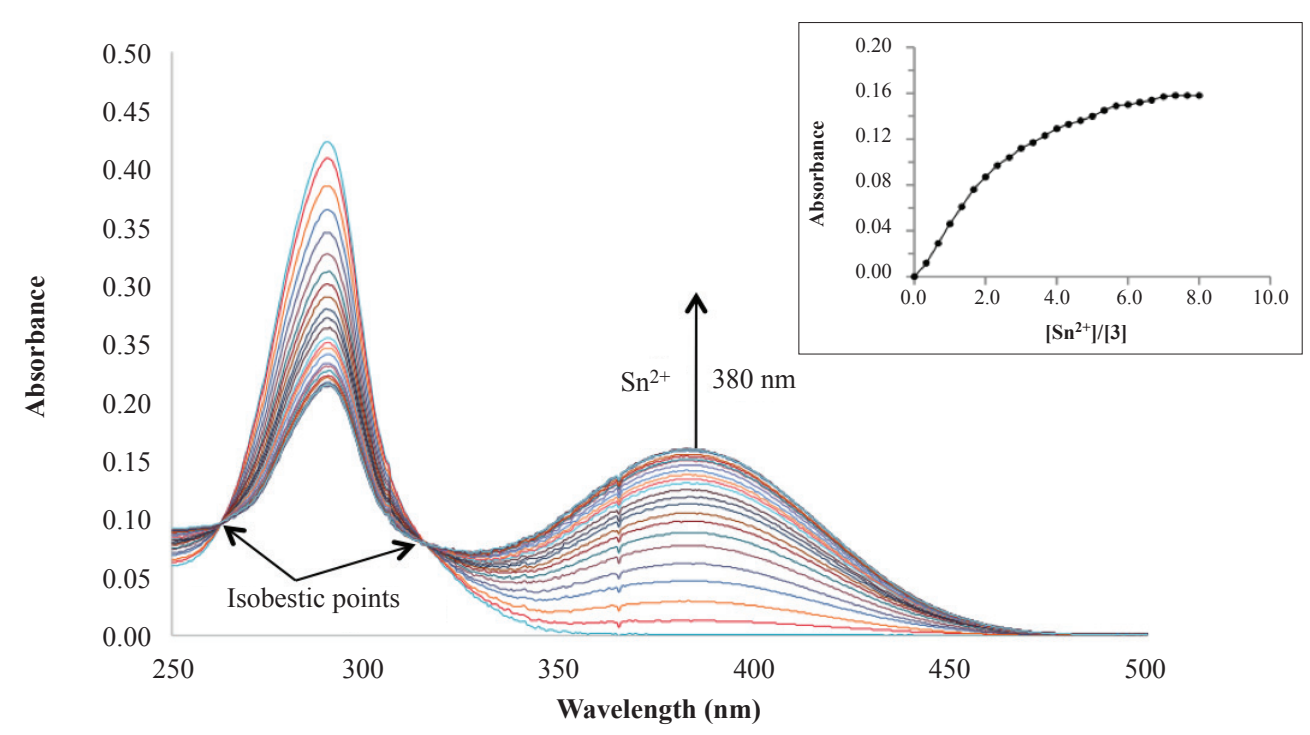

FIGURE 6. Change of absorption spectra of $\mathbf{3}\left(1 \times 10^{-5} \mathrm{M}\right)$ upon gradual addition of $\mathrm{Sn}^{2+}\left(1 \times 10^{-3} \mathrm{M}\right)$ ion concentration $(10-250 \mathrm{~mL})$ in $95 \%$ EtOH. Inset: Plot of UV-vis absorbance at $380 \mathrm{~nm}$ as a function of $\mathrm{Sn}^{2+}$ concentration

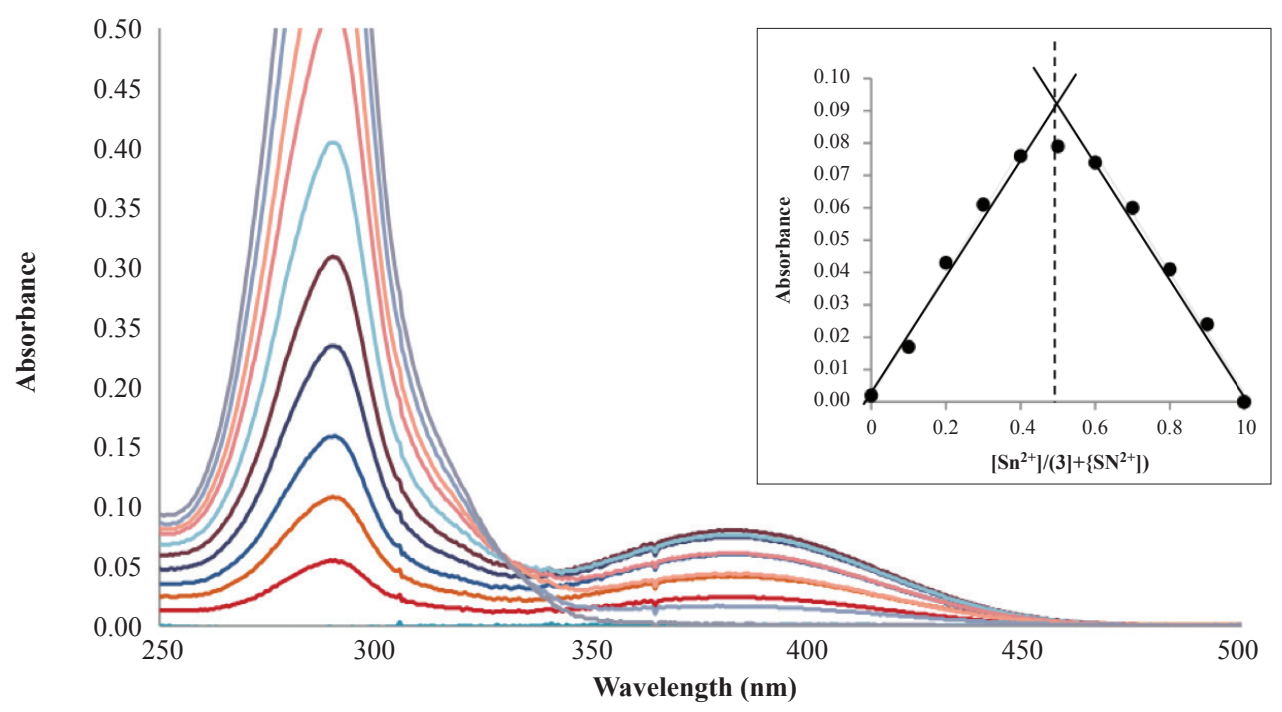

FIGURE 7. Job's plot of 3 and $\mathrm{Sn}^{2+}$ in $95 \% \mathrm{EtOH}$ solution, with a total concentration of $20 \mathrm{mM}\left([\mathbf{3}]+\left[\mathrm{Sn}^{2+}\right]\right)$ and a detection wavelength of $380 \mathrm{~nm}$

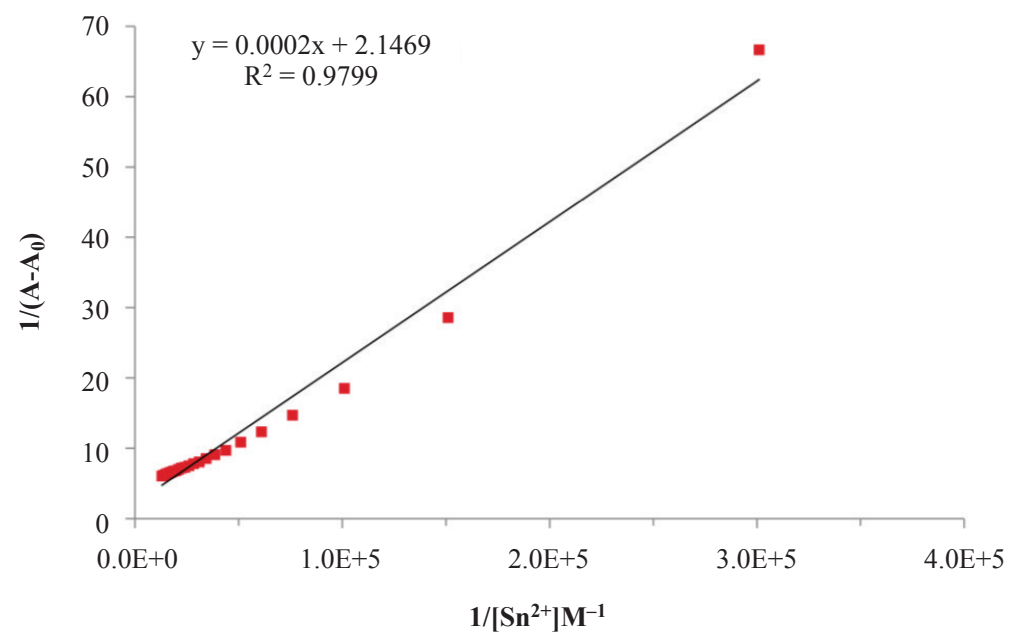

FIGURE 8. Benesi-Hildebrand plot of $1 /(D A)$ versus $1 /\left[\mathrm{Sn}^{2+}\right]$ taken at $380 \mathrm{~nm}$, assuming 1:1 stoichiometry for association between 3 and $\mathrm{Sn}^{2+}$ 


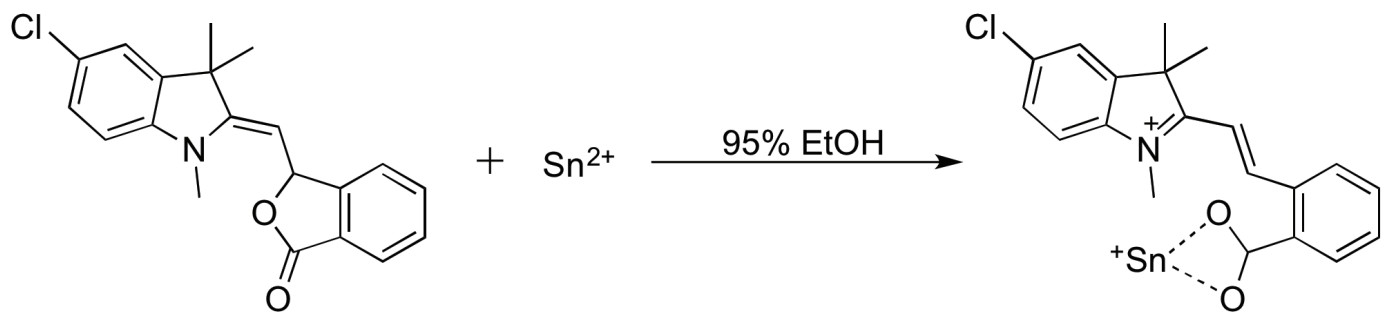

SCHEME 2. Proposed binding mechanism of $\mathbf{3}$ with $\mathrm{Sn}^{2+}$ ion

\section{CONCLUSION}

A phthalide-fused indoline derivative, 3-[(5-chloro1,3,3-trimethylindolin-2-ylidene)methyl]isobenzofuran$1(3 \mathrm{H})$-one (3), was successfully synthesized through a green route of synthesis using solventless microwave irradiation method which yielded $85 \%$ in a short amount of time $(1 \mathrm{~min})$. The compound was characterized by analytical and spectral methods and its structure was further confirmed by chemical crystallography. In conclusion, we report compound $\mathbf{3}$, which is a selective and sensitive chemosensor for $\mathrm{Sn}^{2+}$ ion recognition in $95 \% \mathrm{EtOH}$ solution by colorimetric detection and UV-vis spectroscopy. The 1:1 binding mode was proposed according to the Job's plot and Benesi-Hildebrand analysis.

\section{ACKNOWLEDGEMENTS}

The authors would like to extend their utmost gratitude for the financial support and facilities provided by Universiti Kebangsaan Malaysia (GUP-2017-086) and the Ministry of Higher Education (FRGS-1-2015 ST01-UKM-02/2) to accomplish the project.

\section{REFERENCES}

Adhikari, S., Ghosh, A., Guria, S. \& Sahana, A. 2016. A through bond energy transfer based ratiometric probe for fluorescent imaging of $\mathrm{Sn}^{2+}$ ions in living cells. Royal Society of Chemistry Advances 6(46): 39657-39662.

Azizian, J., Mohammadi, M.K., Firuzi, O., Razzaghi-Asl, N. \& Miri, R. 2012. Synthesis, biological activity and docking study of some new isatin Schiff base derivatives. Medicinal Chemistry Research 21(11): 3730-3740.

Bamfield, P. 2010. Chromic Phenomena: Technological Applications of Colour Chemistry. Royal Society of Chemistry.

Bao, X., Cao, X., Nie, X., Jin, Y. \& Zhou, B. 2014. RBAP, a rhodamine B-based derivative: Synthesis, crystal structure analysis, molecular simulation, and its application as a selective fluorescent chemical sensor for $\mathrm{Sn}^{2+}$. Molecules 19(6): 7817-7831.

Beck, J.J. \& Chou, S.C. 2007. The structural diversity of phthalides from the Apiaceae. Journal of Natural Products 70(5): 891-900.

Chatterjee, N., Mahaling, B., Sivakumar, S. \& Bharadwaj, P.K. 2016. A highly selective and sensitive "turn-on" fluorescence chemosensor for the $\mathrm{Cu}^{2+}$ ion in aqueous ethanolic medium and its application in live cell imaging. Journal of Photochemistry and Photobiology A: Chemistry 330: 110-116.
Chunaev, Y.M., Przhiyalgovskaya, N.M., Kurkovskaya, L.N. \& Gal'bershtam, M.A. 1982. Reaction of the Fischer base with 8-hydroxy-1-naphthaldehydes: Investigation of the reaction products by $13 \mathrm{C}$ NMR spectroscopy. Chemistry of Heterocyclic Compounds 18(11): 1164-1169.

Gangrade, D., Lad, S. \& Mehta, A. 2015. Overview on microwave synthesis-Important tool for green Chemistry. International Journal of Research in Pharmacy \& Science 5(2): 37-42.

Howe, P. \& Watts, P. 2005. Tin and Inorganic Tin Compounds. World Health Organization.

Jadhav, A.G., Shinde, S.S., Lanke, S.K. \& Sekar, N. 2017. Benzophenone based fluorophore for selective detection of $\mathrm{Sn}^{2+}$ ion: Experimental and theoretical study. Spectrochimica Acta Part A: Molecular and Biomolecular Spectroscopy 174: 291-296.

Karmakar, R., Pahari, P. \& Mal, D. 2014. Phthalides and phthalans: Synthetic methodologies and their applications in the total synthesis. Chemical Reviews 114(12): 6213-6284.

Keum, S.R., Lee, M.H., Ma, S.Y., Kim, D.K. \& Roh, S.J. 2011. Novel unsymmetrical leuco-TAM,(2E,2'E)2,2'-\{(E)-4-phenylpent-2-ene-1,5-diylidene $\}$ bis $(1,3,3$ trimethylindoline) derivatives: Synthesis and structure elucidation. Dyes and Pigments 90(3): 233-238.

Landge, S.M., Berryman, M. \& Toeroek, B. 2008. Microwaveassisted solid acid-catalyzed one-pot synthesis of isobenzofuran-1(3H)-ones. Tetrahedron Letters 49(29): 4505-4508.

Li, P. \& Xiao, S. 2016. A highly sensitive and selective sensor based on imidazo[1,2-a]pyridine for $\mathrm{Al}^{3+}$. Journal of Photochemistry and Photobiology A: Chemistry 330(Supplement C): 169-174.

Mathews, T.J., Looney, B.B., Bryan, A.L., Smith, J.G., Miller, C.L., Southworth, G.R. \& Peterson, M.J. 2015. The effects of a stannous chloride-based water treatment system in a mercury contaminated stream. Chemosphere 138: 190-196.

Michael Barbour, P., Podoll, J.D., Marholz, L.J. \& Wang, X. 2014. Discovery and initial structure-activity relationships of $\mathrm{N}$-benzyl tricyclic indolines as antibacterials for methicillinresistant Staphylococcus aureus. Bioorganic \& Medicinal Chemistry Letters 24(24): 5602-5605.

Peeters, K., Zuliani, T., Ščančar, J. \& Milačič, R. 2014. The use of isotopically enriched tin tracers to follow the transformation of organotin compounds in landfill leachate. Water Research 53(Supplement C): 297-309.

Qu, S., Zheng, C., Liao, G., Fan, C., Liu, G. \& Pu, S. 2017. A fluorescent chemosensor for $\mathrm{Sn}^{2+}$ and $\mathrm{Cu}^{2+}$ based on a carbazole-containing diarylethene. Royal Society of Chemistry Advances 7(16): 9833-9839.

Srivastava, K., Singh, S. \& Kumar, H. 2013. Microwave assisted synthesis and photochemical reactions of 3-(amine dithiocarbamyl) phthalides. Pharmaceutical Chemistry 5(1): 137-144. 
Sun, W., Guo, S., Hu, C., Fan, J. \& Peng, X. 2016. Recent development of chemosensors based on cyanine platforms. Chemical Reviews 116(14): 7768-7817.

Wang, J., Lv, M., Wang, Z., Zhou, M., Gu, C. \& Guo, C. 2015. Highly sensitive and selective fluorescent detection of rare earth metal $\mathrm{Sn}$ (II) ion by organic fluorine Schiff base functionalized periodic mesoporous material in aqueous solution. Journal of Photochemistry and Photobiology A: Chemistry 309(Supplement C): 37-46.

Zhu, H., Fan, J., Wang, B. \& Peng, X. 2015. Fluorescent, MRI, and colorimetric chemical sensors for the first-row d-block metal ions. Chemical Society Reviews 44(13): 4337-4366.
Siti Aishah Hasbullah*

Pusat Pengajian Sains dan Teknologi Makanan

Fakulti Sains dan Teknologi

Universiti Kebangsaan Malaysia

43600 UKM Bangi, Selangor Darul Ehsan

Malaysia

*Corresponding author; email: aishah80@ukm.edu.my

Received: 15 September 2017

Accepted: 2 November 2017 